\title{
Attitudes Towards the Use of Mobile Learning: A Case Study from the Gulf Region
}

\author{
http://dx.doi.org/10.3991/ijim.v9i3.4596 \\ Mostafa Al-Emran ${ }^{1,2}$, Khaled Shaalan ${ }^{2}$ \\ ${ }^{1}$ Al Buraimi University College, Al Buraimi, Oman \\ ${ }^{2}$ The British University in Dubai, Dubai, UAE
}

\begin{abstract}
In the last few years, the way we learn has been shifted dramatically from traditional classrooms depending on printed papers into E-learning depending on digital pages. Mobile learning (M-learning) is a recent technology that has been developed rapidly to deliver E-learning using personal mobile devices without posing any restrictions on time and location. In this work, we investigate students and faculty members' attitudes towards the use of M-learning in higher educational institutions within two countries in the Gulf Region (Oman \& UAE). Two questionnaire surveys have been conducted: one for students and another for faculty members. In these surveys, 383 students and 54 instructors have taken part within the study. An independent sample t-test was performed to examine whether there exist a significant difference among the students' attitudes and the faculty members' attitudes towards the use of $M$ learning with regard to gender and country. Results indicated that students in the UAE were more positive towards the use of M-learning than those in Oman. Moreover, results revealed that $99 \%$ of the students own mobile devices, in particular smartphones and tablets, while only $1 \%$ has not. Results of this study could help policy makers for better decision making in building the M-learning infrastructure in the higher educational institutions in general and specifically within the Arab Gulf region.
\end{abstract}

Index Terms-Mobile Learning; Attitudes; Gulf Region.

\section{INTRODUCTION}

Mobile learning (M-learning) recently has been shifted from being a theory to a real valuable improvement supporting the learning environment. M-learning can simply be viewed as the natural evolution of E-learning with more effective communication and powerful personalized mechanisms [1], [2] or a new platform of distance learning [3], [4]. M-learning makes it easy for all students at different ages to study and access the learning material anytime anywhere.

Researchers have defined M-learning in different ways. For example, in [5], M-learning has been defined as a technology emerging form Distance Learning; while in [6] it is stated that M-learning is the next generation of Elearning. Many other authors, such as [7], [8], and [9] have defined M-learning as the learning performed with the utilization of small portable devices, such as smart phones, tablets, PDAs. [10] and [21] described M-learning as the learning that occurs when the learner uses mobile technology in order to learn in anytime anywhere.

In this work, we investigate students' and faculty members' attitudes towards the use of M-learning in higher educational institutions within two neighboring countries in the Gulf region (Oman and UAE). Understanding students and faculty members' attitudes within GCC countries is an important step towards applying M-learning.

\section{LITERATURE REVIEW}

Nowadays, mobile technology has been successfully employed in various sectors, in particular, the educational sector. M-learning is a new research trend in the education field that addresses mobility in different dimensions: mobility of technology, mobility of learners, mobility of educators, and mobility of learning. It is important to investigate M-learning technology before applying it to the learning process in higher education. This requires investigating and examining users' attitudes towards the M-learning technology. The users of M-learning are students and educators.

The research conducted by [11] showed through the use of independent $t$-test that there is no significant difference among the students' attitudes in terms of gender category towards the integration of M-learning and LMS. Authors of [12], [13], [14], and [15] have similarly found that there is no significant difference in gender towards the use of M-learning. In contrast, the research in [16] and [17] have concluded that female students were more positive towards the use of mobile phones rather than males. In addition, the authors of [9] presented in their research study, through the use of independent $t$-test, that female instructors' attitudes were more positive towards M-learning rather than males. However, this observation contradicts with the study conducted by [18] as male instructors' attitudes were more positive towards M-learning than females.

Some authors attempted to investigate whether if there is any significant difference among students' attitudes towards the use of M-learning within two different regions, USA, representing a western country, versus UAE, representing a Middle East development country [17]. Findings indicated that USA students were more positive towards the use of M-learning technology (with $p<0.05$ ) rather than the UAE students. It is worth noting that this study was limited to students' attitudes without considering the faculty members' attitudes.

\section{PROBLEM OF THE STUDY}

M-learning, as one of the recent technologies in the education sector, has brought many opportunities for both students and educators in order to facilitate the learning process. Higher education, particularly as an important venue, has employed M-learning in various universities around the world in order to deliver the learning regardless of place and time. 
We have observed that M-learning has not yet been studied intensively within the Arab Gulf universities. The only exception is the efforts by King Saud University, Saudi Arabia [19] and [9]. Although, UAE has launched the iPad initiative in one of its Federal colleges [20] but this study was incomplete and has focused only on faculty members' attitudes without considering students' attitudes. Moreover, the scope of this study was limited and addressed only the students at the foundation program level without taking into concern students from different specializations. On the other hand, the research by [17] has conducted a comparative study of students' attitudes towards the use of M-learning within UAE and USA. However, this study did not investigate the faculty members' attitudes towards M-learning.

To sum up, there are many issues that have not yet been investigated within the Arab Gulf region, the reason that motivate us to conduct this research. Before embarking on developing any technology, it is important to examine the end-user attitudes towards the use of such technology. Attitudes toward technology help in determining strengths and weaknesses and facilitate the development of the required infrastructure. The end-users of M-learning technology are students and educators. Therefore, our research seeks to answer the following research questions:

- Is there any significant difference among the students' attitudes towards the use of M-learning in terms of gender?

- Is there any significant difference among the students' attitudes towards the use of M-learning in terms of country?

- Is there any significant difference among the faculty members' attitudes towards the use of M-learning in terms of gender?

- Is there any significant difference among the faculty members' attitudes towards the use of M-learning in terms of country?

\section{RESEARCH METHOdOLOGY}

\section{A. Sample and Study Instrument}

A Data set is collected by using the questionnaire survey method. Surveys have been conducted within two neighboring countries in the Arab Gulf region (Oman \& UAE). Surveys are distributed as a hard copy by the researchers themselves and with the help of the faculty members at each academic institution. The Data set was collected in the last quarter of 2014. Five universities from the Arab Gulf region (Oman $(\mathrm{N}=1)$ and $\operatorname{UAE}(\mathrm{N}=4))$ are responded and participated effectively in conducting this research. 383 students have taken part within the study; $(\mathrm{N}=225)$ from Oman and $(\mathrm{N}=158)$ from UAE. 54 instructors have taken part within the study; $(\mathrm{N}=24)$ from Oman and $(\mathrm{N}=30)$ from UAE.

The population of the participated students was selected randomly with different academic majors from different departments in different levels of study. In addition, faculty members were also selected randomly from different nationalities with different academic ranks and experiences.
TABLE I.

STUDENTS' PERSONAL/DEMOGRAPHIC DATA.

\begin{tabular}{|c|l|c|c|}
\hline Variables & \multicolumn{1}{|c|}{ Answers } & Frequency & $\begin{array}{c}\text { Percentage } \\
\%\end{array}$ \\
\hline \multirow{3}{*}{ Gender } & Male & 135 & $35.2 \%$ \\
\cline { 2 - 4 } & Female & 248 & $64.8 \%$ \\
\hline \multirow{3}{*}{ Age } & 18 to 22 & 280 & $73.1 \%$ \\
\cline { 2 - 4 } & 23 to 28 & 72 & $18.8 \%$ \\
\cline { 2 - 4 } & 29 to 35 & 23 & $6 \%$ \\
\cline { 2 - 4 } & Above 35 & 8 & $2.1 \%$ \\
\hline \multirow{5}{*}{ Major } & IT & 194 & $50.7 \%$ \\
\cline { 2 - 4 } & English & 115 & $13.1 \%$ \\
\cline { 2 - 4 } & Business Management & 24 & $30 \%$ \\
\cline { 2 - 4 } & Project Management & 225 & $58.3 \%$ \\
\hline \multirow{5}{*}{ Country } & Oman & 158 & $41.3 \%$ \\
\cline { 2 - 4 } & UAE & & \\
\hline
\end{tabular}

TABLE II.

FACULTY MEMBERS' PERSONAL/DEMOGRAPHIC DATA.

\begin{tabular}{|c|l|c|c|}
\hline Variables & \multicolumn{1}{|c|}{ Answers } & Frequency & $\begin{array}{c}\text { Percentage } \\
\text { \% }\end{array}$ \\
\hline \multirow{3}{*}{ Gender } & Male & 36 & $66.7 \%$ \\
\cline { 2 - 4 } & Female & 18 & $33.3 \%$ \\
\hline \multirow{4}{*}{ Age } & 26 to 35 & 21 & $38.9 \%$ \\
\cline { 2 - 4 } & 36 to 45 & 19 & $35.2 \%$ \\
\cline { 2 - 4 } & 46 to 55 & 10 & $18.5 \%$ \\
\cline { 2 - 4 } & Above 55 & 4 & $7.4 \%$ \\
\hline \multirow{3}{*}{ Academic } & Oman & 24 & $44.4 \%$ \\
\cline { 2 - 4 } & UAE & 30 & $55.6 \%$ \\
\cline { 2 - 4 } & Anstructor & 9 & $63 \%$ \\
\cline { 2 - 4 } & Assistant Professor & 6 & $16.7 \%$ \\
\cline { 2 - 4 } & Associative Professor & 5 & $9.3 \%$ \\
\cline { 2 - 4 } & Professor & & \\
\hline
\end{tabular}

Table I represents the students' personal/demographic data while Table II represents the faculty members' personal/demographic data.

\section{B. Surveys Structures}

Two types of surveys are prepared and distributed: one for students and another for faculty members. The students' survey consists of 28 items (questions) that are divided into three main sections. Each survey consists of 3 sections regardless whether it is for students or faculty members. The first section of the survey consists of $(8$ items) that represents the student/faculty member personal information/demographic data. The second section consists of (10 items) that represents the student/faculty member information regarding the mobile technology. The third section of the survey consists of (10 items) that represents the attitudes towards the use of mobile learning. A five-point Likert Scale, with strongly agree (5), agree (4), undecided (3), disagree (2), and strongly disagree (1), has been used to measure the (10 items).

\section{Measurement Analysis}

Reliability test has been measured for the ten independent variables that represent the attitudes by calculating Cronbach's alpha. The Cronbach's alpha values for the students' attitudes (Alpha $=0.94)$ and for the educators' attitudes (Alpha $=0.93$ ) were greater than 0.7 as per the tables (III, IV) respectively while [17] found this value as $($ Alpha $=0.80)$ for similar purpose. 
TABLE III.

RELIABILITY TEST FOR STUDENTS’ ATTITUDES.

\begin{tabular}{|c|c|c|}
\hline $\begin{array}{c}\text { Cronbach's } \\
\text { Alpha }\end{array}$ & $\begin{array}{c}\text { Cronbach's Alpha Based } \\
\text { on Standardized Items }\end{array}$ & No of Items \\
\hline 0.94 & 0.94 & 10 \\
\hline
\end{tabular}

TABLE IV

RELIABILITY TEST FOR EDUCATORS’ ATTITUDES.

\begin{tabular}{|c|c|c|}
\hline $\begin{array}{c}\text { Cronbach's } \\
\text { Alpha }\end{array}$ & $\begin{array}{c}\text { Cronbach's Alpha Based } \\
\text { on Standardized Items }\end{array}$ & No of Items \\
\hline 0.93 & 0.93 & 10 \\
\hline
\end{tabular}

\section{FINDINGS}

RQ1: Is there any significant difference among the students' attitudes towards the use of M-learning in terms of gender?

An independent samples $t$-test was carried out to examine if there is any statistical significant difference among the students' attitudes towards the use of M-learning with regard to their gender. As shown in Table 5, the results imply that the mean values for both male and female students do not indicate any significant differences among the students in their attitudes in terms of gender. The computed value of $t$ is 1.024 and the significance level is ( $p=0.307, p>0.05$ ). Nevertheless, the mean values indicate that both genders are willing to seize the mobile technology advantages in their education.

TABLE V.

DIFFERENCES BETWEEN STUDENTS’ ATTITUDES IN TERMS OF GENDER.

\begin{tabular}{|l|c|c|c|c|c|c|}
\hline Gender & N & Mean & Std. Dev. & t & Df & Sig. \\
\cline { 1 - 4 } Male & 135 & 3.5030 & 1.09775 & 1.024 & 381 & 0.307 \\
\cline { 1 - 4 } Female & 248 & 3.3919 & 0.96519 & & & \\
\hline
\end{tabular}

Similarly, the research conducted by [11], [12], [13], [14], and [15] have indicated that there were no significant differences among the students' attitudes towards the use of M-learning with regard to their gender. However, [16] and [17] have indicated significant differences among the students' attitudes in terms of gender where female students were more positive towards the use of mobile technology rather than males.

RQ2: Is there any significant difference among the students' attitudes towards the use of M-learning in terms of country?

An independent samples $t$-test was performed in order to test if there is any statistical significant difference among students' attitudes towards the use of M-learning within both countries of residence (i.e. Oman \& UAE). As shown in Table 6 , results indicated a statistical significant difference among the students' attitudes $(p=0.000, p<=$ $0.05)$, the differences were in favor of students resident in UAE. This is reasonable due to the technological resources availability, technology awareness in Dubai, UAE as compared to Al Buraimi, Oman.

TABLE VI.

DIFFERENCES BETWEEN STUDENTS' ATTITUDES IN TERMS OF COUNTRY.

\begin{tabular}{|l|c|c|c|c|c|c|}
\hline Country & N & Mean & $\begin{array}{c}\text { Std. } \\
\text { Dev. }\end{array}$ & \multicolumn{1}{|c|}{ t } & Df & Sig. \\
\hline Oman & 225 & 3.22 & 1.0070 & - & 350.2 & 0.000 \\
\hline UAE & 158 & 3.73 & 0.9487 & 5.05 & & \\
\hline
\end{tabular}

However, [17] indicated when attempted to compare the students' attitudes within two different countries, that USA students were more positive towards the use of Mlearning technology rather than UAE students.

RQ3: Is there any significant difference among the faculty members' attitudes towards the use of $M$ learning in terms of gender?

An independent samples $t$-test was performed to examine if there is any statistical significant difference among the educators' attitudes towards the use of M-learning with regard to their gender. As shown in Table 7, results indicate that the mean scores for both males and females do not indicate any significant differences $(p=0.482, p>$ 0.05 ) among the faculty members in their attitudes with regard to their gender and the calculated value of $t$ is (0.708 ). However, the mean values for both genders revealed that faculty members are ready to use mobile technology for better learning delivery.

TABLE VII

DIFFERENCES BETWEEN FACULTY MEMBERS' ATTITUDES IN TERMS OF GENDER.

\begin{tabular}{|l|c|c|c|c|c|c|}
\hline Gender & $\mathbf{N}$ & Mean & Std. Dev. & t & Df & Sig. \\
\cline { 1 - 5 } Male & 36 & 3.5694 & .86877 & -0.708 & 52 & 0.482 \\
\cline { 1 - 4 } Female & 18 & 3.7389 & .74054 & & & \\
\hline
\end{tabular}

In contrast, [9] revealed through the use of an independent $t$-test that female instructors' attitudes were more positive towards M-learning rather than males. Furthermore, [18] indicated that male instructors' attitudes were more positive towards M-learning than females.

RQ4: is there any significant difference among the faculty members' attitudes towards the use of Mlearning in terms of country?

In order to test if there is any statistical significant difference among the educators' attitudes towards the use of M-learning within residence in both countries (Oman \& UAE); an independent sample $t$-test was carried out. As shown in Table 8 , results indicate that the mean scores for both countries (Oman and UAE) do not reveal any significant differences $(p=0.763, p>0.05)$ among the faculty members in their attitudes with regard to their country and the calculated value of $t$ is $(-0.303)$. However, the mean values for faculty members in both countries could attribute to the fact that faculty members are willing to use the technology into their classrooms but without any noticed difference among the two countries.

TABLE VIII.

DIFFERENCES BETWEEN FACULTY MEMBERS' ATTITUDES IN TERMS OF COUNTRY.

\begin{tabular}{|l|c|c|c|c|c|c|}
\hline Country & N & Mean & $\begin{array}{c}\text { Std. } \\
\text { Dev. }\end{array}$ & t & Df & Sig. \\
\hline Oman & 24 & 3.5875 & 0.7914 & -0.303 & 52 & 0.763 \\
\hline UAE & 30 & 3.6567 & 0.8633 & & & \\
\hline
\end{tabular}

VI. CONCLUSION AND FUTURE WORK

In this research, we have presented the state-of-the-art in M-learning regarding students and educators attitudes towards the use of M-learning in terms of gender and country differences. The gaps that have not yet been covered in the current available research have been highlighted in our study. An attempt was made to examine students 
and faculty members' attitudes within the higher educational institutions in Gulf region (Oman \& UAE). Two surveys have been conducted: one for students and one for faculty members. 383 students and 54 instructors have taken part in this study. An independent samples t-test was performed to examine whether there is any significant difference among the students' attitudes and the faculty members' attitudes towards the use of M-learning with regard to their gender and country. Results indicated that students in UAE were more positive towards the use of M-learning than those in Oman. Results revealed that there was no significant difference among the students in their attitudes in terms of gender. Moreover, results indicated that there was no significant difference among the faculty members in their attitudes with regard to gender and country. Furthermore, Results revealed that $99 \%$ of the students have mobile devices, i.e. either smartphone or tablets, while only $1 \%$ of them have not. Results will help policy makers to take the suitable decision on whether or not to implement M-learning at the Arab Gulf region. As a future work, we are interesting to extend our work and examine the same research questions in the other parts of the Arab Gulf region (e.g. Kuwait, Bahrain and Qatar).

\section{REFERENCES}

[1] Mostakhdemin-Hosseini, A., \& Tuimala, J. (2005, June). Mobile learning framework. In Proceedings IADIS International Conference Mobile Learning(pp. 203-207).

[2] García, A. M. F., \& Esteban, A. P. (2011). Smart m-Learning Reusing Educational Contents. In Highlights in Practical Applications of Agents and Multiagent Systems (pp. 317-323). Springer Berlin Heidelberg. http://dx.doi.org/10.1007/978-3-642-19917$\underline{238}$

[3] Georgiev, T., Georgieva, E., \& Smrikarov, A. (2004, June). Mlearning-a New Stage of E-Learning. In International Conference on Computer Systems and Technologies-CompSysTech, Vol. 4, No. 28, pp. 1-4.

[4] Zhuang, S., Hu, L., Xu, H., \& Tian, Y. (2011, November). MLearning Design Based on Personal Knowledge Management. In Information Management, Innovation Management and Industrial Engineering (ICIII), 2011 International Conference on (Vol. 2, pp. 135-138). IEEE.

[5] Mirski, P.J. and D. Abfalter, (2004). Knowledge enhancement on site-guests' attitudes towards mlearning. Proceeding of the Information and communication technologies in tourism 2004, 11th ENTER International Conference in Cairo, (ICC'04), Cairo, Egypt, pp. 592-600.

[6] Alzaza, N. S., \& Yaakub, A. R. (2011). Students' awareness and requirements of mobile learning services in the higher education environment. American Journal of Economics and Business Administration, 3(1), 95. http://dx.doi.org/10.3844/ajebasp.2011. $\underline{95.100}$

[7] Liaw, S. S., \& Huang, H. M. (2012). A Case of Study of Investigating Users' Acceptance toward Mobile Learning. In Recent Progress in Data Engineering and Internet Technology, pp. 299305. Springer Berlin Heidelberg. http://dx.doi.org/10.1007/978-3642-28798-5 41

[8] Giousmpasoglou, C., \& Marinakou, E. (2013, May). The Future Is Here: m-Learning in Higher Education. In e-Learning" Best Practices in Management, Design and Development of e-Courses: Standards of Excellence and Creativity", 2013 Fourth International Conference on pp. 417-420. IEEE.
[9] Alwraikat, M. A., \& Al Tokhaim, H. (2014). Exploring the Potential of Mobile Learning Use Among Faculty Members. International Journal of Interactive Mobile Technologies (iJIM), 8(3), pp-4. http://dx.doi.org/10.3991/ijim.v8i3.3682

[10] Lam, J., \& Duan, C. G. (2012). A review of mobile learning environment in higher education sector of hong kong: technological and social perspectives. In Hybrid Learning, pp. 165-173. Springer Berlin Heidelberg. http://dx.doi.org/10.1007/978-3-64232018-7 16

[11] Cavus, N. (2011). Investigating mobile devices and LMS integration in higher education: Student perspectives. Procedia Computer Science, 3, pp. 1469-1474. http://dx.doi.org/10.1016/j.procs.2011. $\underline{01.033}$

[12] Rees, H., \& Noyes, J. M. (2007). Mobile telephones, computers, and the internet: sex differences in adolescents' use and attitudes. CyberPsychology \& Behavior, 10(3), pp. 482-484. http://dx.doi.org/10.1089/cpb.2006.9927

[13] Wang, Y. S., Wu, M. C., \& Wang, H. Y. (2009). Investigating the determinants and age and gender differences in the acceptance of mobile learning. British Journal of Educational Technolo$g y, 40(1), \quad$ pp. 92-118. http://dx.doi.org/10.1111/j.1467-8535. 2007.00809.x

[14] Uzunboylu, H., Cavus, N., \& Ercag, E. (2009). Using mobile learning to increase environmental awareness. Computers \& Education, 52(2), 381-389. http://dx.doi.org/10.1016/j.compedu.2008. 09.008

[15] Yang, S. H. (2012). Exploring College Students' Attitudes and Self-Efficacy of Mobile Learning. Turkish Online Journal of Educational Technology-TOJET, 11(4), pp. 148-154.

[16] Taleb, Z., \& Sohrabi, A. (2012). Learning on the move: the use of mobile technology to support learning for university students. Procedia-Social and Behavioral Sciences, 69, pp. 11021109. http://dx.doi.org/10.1016/j.sbspro.2012.12.038

[17] Khaddage, F., \& Knezek, G. (2013, July). iLearn via mobile technology: A comparison of mobile learning attitudes among university students in two nations. In Advanced Learning Technologies (ICALT), 2013 IEEE 13th International Conference on pp. 256-258. IEEE.

[18] Uzunboylu, H., \& Ozdamli, F. (2011). Teacher perception for m-learning: scale development and teachers' perceptions. Journal of Computer Assisted Learning, 27(6), pp. 544-556. http://dx.doi.org/10.1111/j.1365-2729.2011.00415.x

[19] Al-Fahad, F. N. (2009). Students' Attitudes and Perceptions towards the Effectiveness of Mobile Learning in King Saud University, Saudi Arabia. Online Submission, 8(2).

[20] Hargis, J., Cavanaugh, C., Kamali, T., \& Soto, M. (2014). A federal higher education iPad mobile learning initiative: triangulation of data to determine early effectiveness. Innovative Higher Education, 39(1), pp. 45-57. http://dx.doi.org/10.1007/s10755013-9259-y

[21] Al Emran, M., \& Shaalan, K. (2014, March). E-podium Technology: A medium of managing Knowledge at Al Buraimi University College via M-learning. In BCS International IT Conference.

\section{AUTHORS}

Mostafa Al-Emran is the Head of Technical Support and a Researcher in Computer Science, Al Buraimi University College, Oman (e-mail: malemran@buc.edu.om).

Khaled Shaalan is a full professor at The British University in Dubai, UAE. He is an Honorary Fellow at the School of Informatics, University of Edinburgh, UK. (e-mail: khaled.shaalan@buid.ac.ae).

Submitted, 09 March 2015. Published as resubmitted by the authors on 09 April 2015. 